\title{
Two new ichneumonid species of the genera Callidora Förster, 1869 and Nepiesta Förster, 1869 (Hymenoptera: Ichneumonidae: Campopleginae) from the Russian Far East
}

\section{Ава новых вида наездников-ихневмонид родов Callidora Förster, 1869 и Nepiesta Förster, 1869 (Hymenoptera: Ichneumonidae: Campopleginae) с Аальнего Востока России}

\author{
D.R. Kasparyan \\ A.P. Каспарян
}

\begin{abstract}
Zoological Institute, Russian Academy of Sciences, St. Petersburg 199034, Russia. E-mail: hymenopt@zin.ru Зоологический институт Российской академии наук, С.-Петербург 199034, Россия.
\end{abstract}

KEY WORDS: Hymenoptera, Ichneumonidae, Campopleginae, new species, Callidora, Nepiesta, Russian Far East.

КЛЮЧЕВЫЕ СЛОВА: Нуmenoptera, Ichneumonidae, Campopleginae, новые виды, Callidora, Nepiesta, Дальний Восток России.

ABSTRACT. Two new ichneumonid species of the subfamily Campopleginae, Callidora rasnitsyni sp.n. and Nepiesta rasnitsyni sp.n. are described from the Russian Far East.

PЕЗЮМЕ. С Дальнего Востока России описываются два новых вида ихневмонид из подсемейства Campopleginae - Callidora rasnitsyni sp.n. and Nepiesta rasnitsyni sp.n.

\section{Introduction}

Ichneumonid wasps of the subfamily Campopleginae of the Russian Far East are rather poorly studied [Townes et al., 1965; Yu, Horstmann, 1998; Khalaim, Kasparyan, 2007]. Two new species of the genera Callidora Förster, 1869 and Nepiesta Förster, 1869 from this region are described here. The genus Nepiesta includes only ten West Palaearctic species; it was revised earlier by Horstmann [1973, 1977]. Two Palaearctic and two Nearctic species of the genus Callidora together with the only species from the Philippines have been described up to now. The keys to all Palaearctic species of Nepiesta and the two Palaearctic species of Callidora were given by Kasparyan [1981]; non-Palaearctic species of Callidora were revised by Tigner [1969]. From those two genera, only Callidora albovincta (Holmgren, 1860) has been previously recorded in the fauna of the Russian Far East [Kasparyan, Dbar, 1985].

Hosts of Callidora species are unknown, however, a chrysomelid beetle Colaphellus sophiae (Schaller, 1783) was recorded as a host of Nepiesta tarsalis (Szé- pligeti, 1911) [Müller, 1950; Jolivet, Théodoridès, 1952]. Data on species distribution and taxonomic bibliography of both these genera are given by $\mathrm{Yu}$ and Horstmann [1997]. The types of the new species are stored in the Zoological Institute of the Russian Academy of Sciences (St. Petersburg, Russia) (ZISP).

Both new species are named after Alexandr P. Rasnitsyn, my colleague and friend, a well-known Russian hymenopterist and palaeontologist, and in recognition of his long-term work in Ichneumoninae systematics.

\section{Taxonomic part}

Callidora rasnitsyni $\mathbf{s p .} \mathbf{n}$.

Figs 1-5.

TYPE MATERIAL. Holotype: + , Russia, Primorskiy Territory, Verkhne-Ussuriyskiy station, 40 km SE Chuguevka, 23.VIII.1978 (Kasparyan) (ZISP). Paratype: Russia, Primorskiy Territory, Khasan District, Narva stream, SW Barabash, 5.VIII.1978 (Kasparyan), 1 ㅇ (without metasoma) (ZISP).

DIAGNOSIS. The new species is closely related to Callidora albovincta, but differs from it in having reddish rufous coloration of the most part of metasoma and entirely brown colour of antennae. C. rasnitsyni sp.n. can be distinguished from both Nearctic species of this genus by the higher number of antennal segments (38 vs. $27-33$ segments in the Nearctic species). This new species also differs from $C$. atrognatha Tigner, 1969 from the Philippines by having yellow mandibles and tegulae and the higher number of antennal segments.

DESCRIPTION. Female (holotype). Fore wing 5.5 $\mathrm{mm}$. Antenna with 38 flagellomeres; first flagellomere 

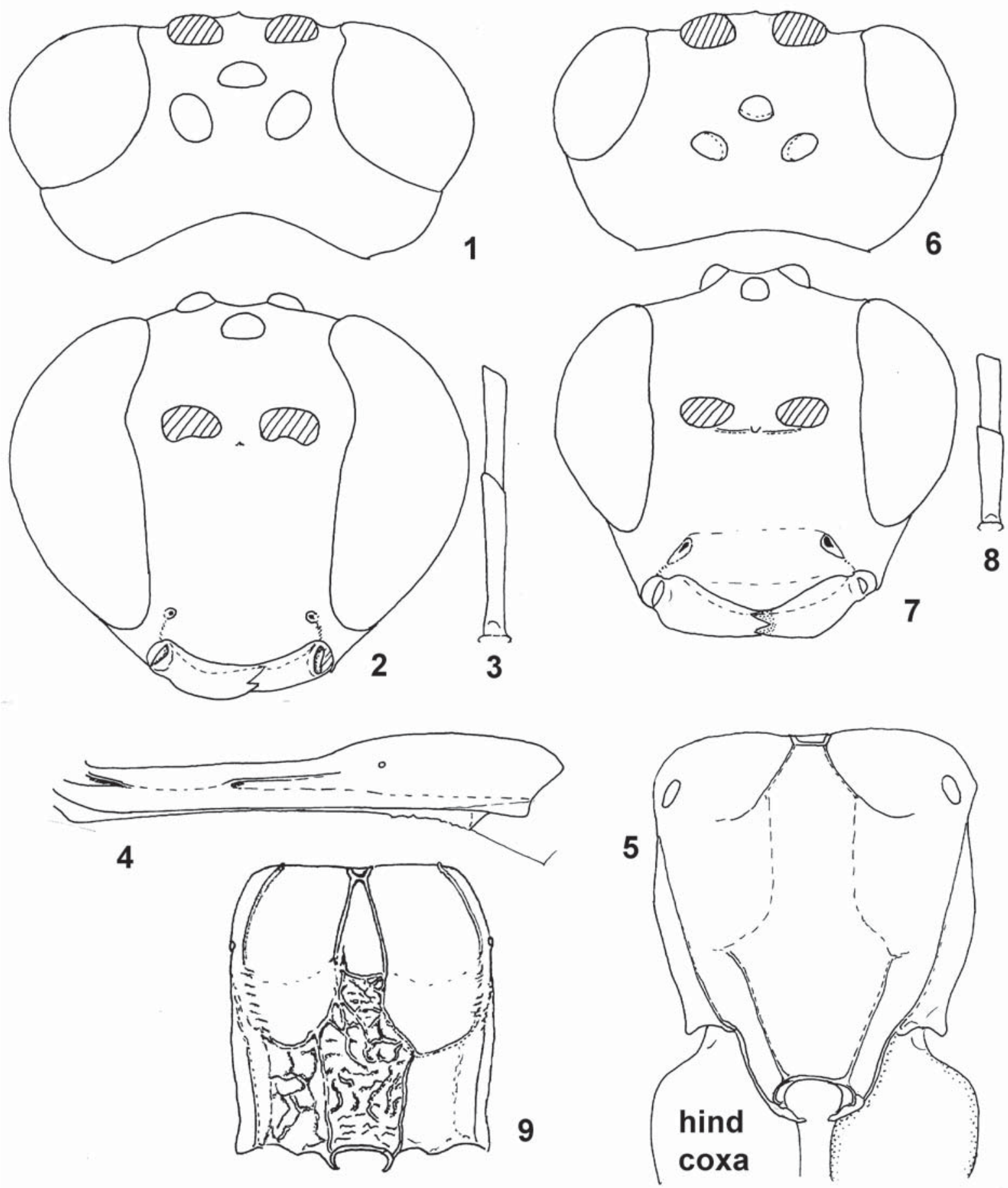

Figs 1-9. Callidora rasnitsyni sp.n. (1-5) and Nepiesta rasnitsyni sp.n. (6-9). 1,6 - head, dorsal view; 2, 7 — head, frontal view; 3 , 8 - two basal flagellomeres of antenna; 4 - first metasomal segment, lateral view; 5, 9 - propodeum, dorsal view.

Рис. 1-9. Callidora rasnitsyni sp.n. (1-5) и Nepiesta rasnitsyni sp.n. (6-9). 1, 6 - голова, вид сверху; 2, 7 — голова, вид спереди; 3, 8 - два базальных флагелломера усика; 4 - первый сегмент метасомы, вид сбоку; 5, 9 - проподеум, вид сверху.

6.0 times as long as apical width; combined length of two basal flagellomeres 0.84 times maximum diameter of eye (Figs 2, 3). Head (dorsal view) strongly narrowed beyond eyes (Fig. 1). Dorsal ocelli large, distance from lateral ocellus to eye 0.6 times diameter of ocellus. Inner orbits of eyes subparallel, with deep concavity near antennal sockets (Fig. 1). Malar space 0.33 times as long as basal width of mandible. Upper tooth of mandible a little longer than lower tooth. Clypeus not separated from face by distinct impres- 
sion; clypeal foveae rather small and situated close to eye (Fig. 2). Temples mat, finely alutaceous, with indiscernible punctures. Face, frons, clypeus and mesoscutum mat, with moderately large and relatively shallow punctures above granulation; frons and middle of face very closely punctate, punctures partly confluent; clypeus with a little more sparse punctures, distances between punctures one or two their diameters. Pronotum with weak epomia, its dorsolateral margin with fine rugosity but without discernible punctures, its lower corners with coarse rugae. Mesopleuron with moderately large superficial punctures, punctures partly confluent and form small-celled sculpture; speculum entirely granulate and mat. Metapleuron and propodeum mat, coarsely scabrous, without distinct punctures. All carinae of propodeum very fine, partly obliterated (as in paratype; Fig. 4); basal area short, separated from areola; areola merged with apical area; costulae present.

Pterostigma narrow, about 5.0 times as long as wide; areolet small, with long petiole; nervulus interstitial; nervellus intercepted in lower 0.3 ; discoidella translucent, long and straight. Legs slender, hind femur 6.0 times as long as wide; proportions of 1 st to 5 th segment of hind tarsus $8: 3.5: 2.1: 1.3: 1.45$; second segment about 2.5 times as long as fifth segment and 0.7 times as long as inner spur of hind tibia. Claws of hind tarsus with three to four strong teeth.

Metasomal tergite 1 slender (Fig. 5), 5.0 times as long as its maximum width; its dorsolateral longitudinal carinae fine, stretching back to middle part of petiole but not reaching spiracles. Apical part of sternite situated in basal 0.45 of postpetiole. Second tergite 2.5 times as long as its width on hind margin, with spiracles in its apical 0.6; thyridia narrow, long, lying close to lateral margin of tergite between spiracles and base of tergite. Metasoma strongly compressed beyond tergite 2. Ovipositor sheath short, about as long as second segment of hind tarsus.

Antenna ventrally uniformly brown, dorsally dark brown. Head and mesosoma black, mandibles yellow with reddish teeth, palpi whitish, tegulae yellow. Coxae brownish black; fore and mid trochanters yellowish, legs beyond trochanters pale rufous. Hind trochanters brownish, hind leg beyond trochanters almost uniformly reddish rufous, hind tarsus brownish. Metasoma from apex of tergite 2 uniformly reddish rufous, tergite 1 and basal 0.75 of tergite 2 black.

VARIABILITY. Paratype is similar to holotype in its main features, but areas of propodeum are more finely delineated by carinae.

Male unknown.

\section{Nepiesta rasnitsyni sp.n.}

Figs 6-9.

TYPE MATERIAL. Holotype: + , Russia, Khabarovsk, Khekhzir Ridge, 18th km of highway Khabarovsk - Vladivostok, forest, 4.VI.1983 (Kasparyan) (ZISP). Paratypes. Russia, Khabarovsk, Khekhzir Ridge, 24th km of highway Khabarovsk - Vladivostok, 29, 30.V.1983 (Kasparyan), 2 우 (ZISP); same locality, 24th km of highway Khabarovsk - Vladivostok, Levaya River, 11.VI.1983
(Kasparyan), 1 ㅇ (ZISP); Khabarovsk Territory, 20 km N Bikin, Boitsovo, 25-27.V.1993 (Belokobylskij), 1 우 (ZISP).

DIAGNOSIS. $N$. rasnitsyni sp.n. differs from most other members of its genus in the red coloration of tergites 2-4 and legs (except for blackish coxae), and yellowish tegulae. These diagnostic characters are also known in $N$. hungarica Szépligeti, 1916; N. rasnitsyni can be separated from it by having face and clypeus (except for its lower 0.3 ) entirely mat, antenna with 26-28 flagellomeres (21 flagellomeres in $N$. hungari$\mathrm{ca}$ ), polished speculum, longer areola of propodeum (Fig. 9), and anterior part of nervellus straight (arched at base of wing in $N$. hungarica).

DESCRIPTION. Female (holotype). Fore wing 4.6 $\mathrm{mm}$. Antenna with 26 flagellomeres. Head (dorsal view) distinctly narrowed beyond eyes (Fig. 6). Head and mesosoma mat, moderately coarsely and closely punctate above fine granulation. Distance from lateral ocellus to eye twice as long as maximum diameter of ocellus. Malar space about 0.65 times as long as basal width of mandible. Clypeal foveae long, oblique (Fig. 7). Punctures on clypeus a little larger and sparser than those on face; lower 0.3 of clypeus polished, lamelliform, slightly impressed, with sharp lower margin. Epomia absent. Speculum polished, rather small, with granulate area before. All carinae of propodeum very fine, strongly obliterated or hidden due to strong rugosity (Fig. 9); area basalis very small, areola moderately narrow, about 2.0 times as long as wide; anterior 0.4 of areola almost smooth, its posterior 0.6 and apical areas in coarse rugae. Fore wing without areolet; distance between $\mathrm{rm}$ and second recurrent vein 0.28 times as long as $\mathrm{rm}$; nervulus postfurcal; nervellus intercepted at posterior 0.16 , its anterior part straight. Hind femur 4.7 times as long as wide; proportion of 1 st to 5 th segments of hind tarsus $5.5: 2.3: 1.8: 1.2: 1.45$.

First metasomal segment without dorsal and dorsolateral carinae; postpetiole as long as wide, finely granulate and with distinct sparse punctures; tergite 2 as long as its width on hind margin. Ovipositor sheath not projecting beyond tip of metasoma.

Antennae blackish. Head and mesosoma black; mandible reddish with darkened base and teeth, palpi brownish; tegulae reddish yellow. Coxae black, legs beyond coxae reddish rufous, hind spurs pale, extreme apex of hind femur and hind tibia fuscous, tarsi partly brownish (especially 3rd to 5th segment). Metasoma with black base and apex, posterior 0.4 of tergite 2, tergites 3 and 4 entirely, and epipleura of tergite 5 reddish.

VARIABILITY. Fore wing 4.4-5.0 mm. Antenna with 26-28 flagellomeres.

Male unknown.

ACKNOWLEDGEMENT. The present work was partly supported by the grant from the Russian Foundation for Basic Research (No. 10-04-00265).

\section{References}

Horstmann K. 1973. Revision der Gattung Nepiesta Förster (mit einer Übersicht über die Arten der Gattung Leptoperilissus 
Schmiedeknecht) (Hymenoptera, Ichneumonidae) // Polskie Pismo Entomologiczne. T.43. S.729-741.

Horstmann K. 1977. Campopleginae aus Jordanien und Libanon (Hymenoptera, Ichneumonidae) // Annales Historico-Naturales Musei Nationalis Hungarici. T.69. P.195-199.

Jolivet P., Théodoridès J. 1952. Les parasites, phorétiques et prédateurs des Chrysomeloidea (Coleoptera) // Bulletin de l'Institut Royal des Sciences Naturelles de Belgique. T.28. No.20. P.119.

Kasparyan D.R. 1981. [11 Ctenopelmatinae. 12 Phrudinae. 13 Tersilochinae. 14 Cremastinae. 15 Campopleginae. 16 Ophioninae] // Medvedev G.S. (ed.). A key to insects of the European part of the USSR. Hymenoptera, Ichneumonidae. Vol.3. No.3. P.316-431 [in Russian].

Kasparyan D.R., Dbar R.S. 1985. [On the taxonomy of ichneumonid wasps of the subfamily Campopleginae (Hymenoptera, Ichneumonidae) in the Far East of the USSR] // Proceedings of the Zoological Institute, Academy of Sciences of the USSR.
Vol.132. P.40-53 [in Russian].

Khalaim A.I., Kasparyan D.R. 2007. [19. Subfam. Campopleginae] // Lelej A.S. (ed.). Key to insects of the Russian Far East. Neuropteroidea, Mecoptera, Hymenoptera. Vladivostok: Dal'nauka. Vol.4. Pt.5. P.597-632 [in Russian].

Müller F.P. 1950. Über Schadauftreten und Biologie von Colaphellus sophiae Schall. (Chrysomel.) // Zeitschrift für Angewandte Entomologie. Bd.31. S.591-608.

Tigner T.C. 1969. Three new species and a key for the genus Callidora (Hymenoptera: Ichneumonidae) // Michigan Entomologist. Vol.2. P.36-39.

Townes H.K., Momoi S., Townes M. 1965. A catalogue and reclassification of the eastern Palaearctic Ichneumonidae // Memoirs of the American Entomological Institute. Vol.5. P.1-661.

Yu D.S., Horstmann K. 1997. A catalogue of world Ichneumonidae (Hymenoptera) // Memoirs of the American Entomological Institute. Vol.58. P.1-1558. 